\section{Corporate largesse}

\section{More tax breaks?}

A tax incentive measure designed to stimulate corporate support for scientific research in US universities has taken a first step towards congressional approval. A comprehensive tax bill sponsored by Representative James M. Shannon has passed a House Ways and Means Committee panel on its way to the full committee.

Representatives from major universities, including the presidents of the Massachusetts Institute of Technology and Stanford, have testified at House hearings along with prominent industry members in support of the legislation. They hope that the Shannon bill will offset the expected losses from the Reagan budget by attracting more than $\$ 500$ million to university research next year.

Three sections of the tax incentive plan would specifically benefit universities:

- A 25 per cent tax credit for contributions from corporations to a "research reserve fund" that would guarantee against shortfalls in research funding. This money, which could be up to 5 per cent of a corporation's income, can remain in the fund for four years drawing interest, while the taxpayer receives more credit for additional money added.

- A 25 per cent tax credit for money contributed to any form of research and development at universities or private laboratories if the total contribution exceeds the average amount given by that corporation over the previous three years.

- Tax deductions to corporations giving charitable contributions of scientific or educational equipment, based on the market value rather than production cost.

The "research reserve fund" would actually give businesses a larger tax credit because a contributing corporation would receive an additional deduction of up to 46 per cent when its money was transferred from the fund to a specific university.

Opposition to the bill comes from those who believe it would entail a major loss of federal revenue (around $\$ 207$ million), but the White House has indicated in informal discussion with House members that it would definitely consider supporting it.

Besides bringing more corporate dollars to American academic research, which at present makes up less than 5 per cent of the total given to universities, supporters of the bill say it would foster closer ties between university scientists and applied research.

Passage of the bill may, however, be hindered by the lack of a unified academic voice. Some smaller universities feel that it will hurt them because most money will be directed towards the larger institutions. But insiders say the bill has a bright future because Senate Finance Committee chairman, Senator Robert Dole, has expressed great interest in its passage.

Michael D. Stein
Yugoslavian university unrest

\section{Cuts feared}

The University of Pristina, the third largest university in Yugoslavia, may becut to about one fifth its present size following the political unrest of the last three months, which began in the university.

Pristina is the capital of the autonomous province of Kosovo which forms part of the Republic of Serbia but enjoys considerable local self-government. It ranks as one of the less developed areas of Yugoslavia, and hence, over the last few years, has benefited considerably from federal development schemes. Under such a scheme, the University of Pristina has grown during the last decade to a student body of almost 50,000, instead of the 10,000 originally planned, an expansion deemed necessary by Belgrade for "the overall development of Kosovo and the advancement of national equality". (The population of Kosovo is predominantly Albanian).

However, the growth in numbers was not matched by a commensurate expansion of student facilities, and on 11 March there was a small demonstration of students demanding improvements in hostel accommodation and canteen food. The local and university authorities seem to have over-reacted when restoring order and almost inevitably, the demonstrations escalated and became more political in nature. By the end of April, demonstrators were demanding outright secession of Kosovo from the federation and even a link-up with Albania; cultural and scientific exchange programmes between Yugoslavia and Albania were subsequently cut.

Although by now the demonstrations had spread far beyond the student body, the university was still regarded as their focus. Accordingly, on 18 May, Pazajit Nusi, vice president of Kosovo Assembly's executive council, and Dr Imer Jaka, Secretary for Education, Science and Culture, resigned. The same evening there was another on-campus demonstration, and the next day the executive council ordered the university and all other institutions of higher education in Kosovo to close for the vacation.

The university party organization, in the meantime, had set up its own action committee. According to one report more than 500 members of the philosophical faculty have been expelled from the Party, and four persons suspected of organizing the demonstrations have been expelled from the university. Also, various abuses in the university structure have been uncovered. At the same time, the action committee was highly critical of the Belgrade authorities and media for exaggerating the situation, and was particularly critical of Milan Daljevic, Executive Secretary of the (Federal) Central Committee Praesiduim, who had spoken of the University of Pristina as "a fortress of nationalism" and had alleged that not a single professor had made any political statement condemning "enemy actions"'. An official protest has been sent to the Central Committee Praesidium.

To offset the incomplete, and often incorrect, media coverage, the action committee called for a complete dossier on the unrest to be prepared.

With so few jobs available for existing graduates and 55,000 young people now receiving higher education in Kosovo, the suggestions from Belgrade that the university be cut back to its original 10,000 places and funding switched to other educational needs, poses a real threat to the University of Pristina. So far the action committee has made no explicit reference to the suggestion, but has merely suggested that future admissions be tailored more closely to "social needs". $\quad$ Vera Rich

\section{US security worries}

\section{No compromise}

\section{Washington}

In a move reflecting deep-seated disagreement over how far national security arguments should influence the procedures of basic research, scientists on two advisory committees to the National Science Foundation (NSF) have criticized proposals by the American Council on Education (ACE) that papers containing potentially sensitive results in computer research be voluntarily submitted to national security authorities for review before publication.

The proposal was made by a study group on public cryptography set up by ACE at the suggestion of the National Security Agency (NSA). This followed a series of incidents in which NSA had sought to restrain the dissemination of unclassified data on the grounds that they could threaten national security by assisting the development of techniques to make and break codes.

NSA already accepts in principle the proposals of the study group, and has outlined to several professional organizations and their scientific journals the group's conclusions under which suggestions for changes, deletions or publication delays would be made on manuscripts submitted to the agency. ACE announced last month that "the intelligence and academic communities have agreed on guidelines for voluntary review before publication of computer cryptography articles'. However, members of the mathematical and computer sciences advisory committee of NSF have said that voluntary submission to prepublication review represents a "direct and serious threat to NSF's charter of furthering basic scientific research". A report, prepared by a subcommittee under the chairmanship of Dr John Guttag, says that the conclusions of the ACE study 